\title{
Otwórzmy świat... O komunikacji, kontakcie ze światem i zaburzeniach u osób ze spektrum autyzmu, red. A. Kominek, Kielce 2018, ss. 214
}

\author{
Marta Wrześniewska-Pietrzak \\ Wydział Filologii Polskiej i Klasycznej, Uniwersytet im. Adama Mickiewicza w Poznaniu, \\ ul. Fredry 10, 61-701 Poznań, Polska; \\ e-mail: martaw-p@amu.edu.pl
}

Recenzowana publikacja przygotowana pod redakcją naukową Andrzeja Kominka powstała z okazji 10-lecia Stowarzyszenia „Otwórzmy Świat” na Rzecz Osób z Autyzmem i Zaburzeniami Pokrewnymi. Realizuje tym samym jeden z celów działalności stowarzyszenia - upowszechnianie wiedzy na temat autyzmu. Nie jest to pierwsza publikacja, wcześniej bowiem wydane zostały inne opracowania: Aspi-racje. Naukowy obraz osób z zespotem Aspergera w aspekcie kulturowym, terapeutycznym i komunikacyjnym, red. Andrzej Kominek (Kielce 2016) - tom stanowiący swego rodzaju kampanię informacyjną związaną z obchodami Światowego Dnia Świadomości Autyzmu, który przypada corocznie 2 kwietnia; cenna jest też druga z publikacji, wydana w 2014 roku - Światu potrzeba umystów różnego rodzaju. Opowieści o ludziach z autyzmem, której tytuł nawiązuje do słów Temple Grandin. Składa się ona z części naukowej, opisującej w sposób syntetyczny problematykę autyzmu, a także artystycznej, w której zebrane zostały teksty o osobach z autyzmem. Stanowią one pokłosie konkursu literackiego, który odbył się w 2014 roku na Uniwersytecie Jana Kochanowskiego w Kielcach.

Patrząc na dwa wcześniejsze tomy, zauważyć można, że zarysowują one pewnego rodzaju kierunek działań zmierzających do podnoszenia świadomości społecznej na temat autyzmu nie tylko wśród specjalistów czy naukowców. Na recenzowany tom wydany w 2018 roku składa się 12 artykułów, które podzielone zostały na trzy części. W pierwszej znajduje się tekst Andrzeja Kominka, który wyjaśnia metaforyczne znaczenie nazwy stowarzyszenia „Otwórzmy Świat”. Nawiązuje ona do metafory otwieranych drzwi zastosowanej przez Temple Grandin w autobiograficznej książce pt. Byłam dzieckiem autystycznym. Autor, opisując doświadczenie przedstawione przez Grandin związane z otwarciem drzwi i przejściem przez nie, pokonaniem bariery, podkreśla wagę ponoszenia kompetencji komunikacyjnych związanych z rozumieniem (w przypadku osób ze spektrum 
autyzmu - brakiem rozumienia) metafory stanowiącej - jak w przypadku Grandin - dojrzewanie, możliwość kontaktu werbalnego, komunikacyjnego z drugim człowiekiem, a także rozwój myślenia. Na gruncie tych rozważań autor uwypukla trudności funkcjonowania osób ze spektrum autyzmu w świecie bez metafory.

W części drugiej znalazły się teksty odnoszące się do komunikacji, napisane przez specjalistów z takich dziedzin jak psychologia, językoznawstwo, a także szeroko rozumiane nauki społeczne. Otwiera ją artykuł Agnieszki Rosińskiej-Mamej, która przedstawia czytelnikowi wagę kompetencji komunikacyjnej w skutecznym porozumiewaniu się ludzi. Autorka dokonuje też przeglądu podstawowych dla językoznawstwa pojęć, jak: kod, gramatyka uniwersalna, a korzystając z dokonań lingwistów, psycholingwistów, psychologów (w tym W. Pisarka, N. Chomsky'ego, D. Hymesa, J. Kowalikowej, R. Jakobsona, A. Furdala, J. Porayskiego-Pomsty, I. Kurcz), wyjaśnia różnice i relacje między kompetencją językową (gramatyczną) a kompetencją komunikacyjną (komunikatywną). Ponadto przedstawia terminy ważne dla opisu funkcjonowania komunikacyjnego osób ze spektrum autyzmu teorię umysłu oraz neurony lustrzane. Ponadto badaczka przedstawia też definicję autyzmu oraz w sposób syntetyczny ukazuje zaburzenia komunikacyjne, które są charakterystyczne dla osób z zespołem Aspergera. W konkluzji dotyczącej komunikacyjnego funkcjonowania osób z zespołem Aspergera stwierdza ona: „Być może jest tak, że ludzie z autyzmem nie tyle nie mają kompetencji komunikacyjnej, co mają inną kompetencję komunikacyjną niż osoby neurotypowe, informują otoczenie o swoich potrzebach czy oczekiwaniach w taki sposób, w jaki umieją to zrobić, a nie w taki, jaki jest powszechnie przyjęty" (s. 46).

W kolejnym tekście Joanna Senderska stawia pytanie: czy autyści umieją czytać w umysłach zwierząt?, na które jednak nie odpowiada. Stanowi ono bowiem pretekst do przywołania postaci i dokonań Temple Grandin, wysoko funkcjonującej osoby z autyzmem. Autorka stara się przedstawić fenomen działalności jednej z pierwszych osób, która publicznie przedstawiła swoje spostrzeżenia na temat własnego funkcjonowania jako osoby z autyzmem. Joanna Senderska, zauważając dokonania Grandin na gruncie naukowym, które wiążą się z humanitarnym traktowaniem zwierząt, wykazała, że dokonywane przez Grandin analizy sposobu postrzegania świata przez zwierzęta, przyjmowanie ich perspektywy rzucają pewne światło na sposób funkcjonowania umysłu osób ze spektrum autyzmu (m.in. nastawienie na dane wzrokowe, skupienie się na szczegółach). Autorka artykułu przedstawia też przemyślenia samej Grandin na temat podobieństw w funkcjonowaniu mózgów zwierząt i autystów - np. mniejsze i słabiej rozwinięte płaty czołowe u zwierząt i gorzej pracujące, odpowiadające za uogólnianie i abstrahowanie, płaty czołowe u autystów.

Ciekawy problem związany ze swego rodzaju „nadnaturalnymi” zdolnościami do komunikowania się z osobami niepełnosprawnymi intelektualnie i nieneurotypowymi przedstawia na przykładzie duszpasterza ks. Henriego Nouwena Andrzej Kominek. Badacz, charakteryzując postać holenderskiego księdza, żyjącego w latach 1932-1996, skupia uwagę na okresie, w którym Nouwen, zrezygnowawszy 
z pracy na stanowisku profesora uniwersytetu w USA, podjął się pracy duszpasterskiej w domu wspólnoty L'Arche - Daybreak w Toronto. Autor podkreśla zarówno specyficzne cechy ks. Nouwena, jego ponadprzeciętną empatię, jak i wysoko rozwiniętą kompetencję komunikacyjno-społeczną. Andrzej Kominek poprzez analizę występującej w pismach Nouwena metafory (a w zasadzie megametafory) kielicha pokazuje, jak dobrze ten skrypt kulturowy odzwierciedla wagę świętowania Eucharystii, a ponadto pozwala na wykorzystanie tego scenariusza metaforycznego do uproszczenia przekazu poprzez odniesienie do znanego z życia schematu, jego wizualności oraz potencjału narracyjnego. Jak przekonuje Andrzej Kominek, „Przystosowanie Eucharystii (jak i wszelkich form przekazywania wiary i świętowania) do odbiorcy musi zawsze uwzględniać twórcze przesunięcia znaczeń elementów języka (werbalnego i niewerbalnego) w celu aktualizacji i pamięci o tajemnicach wiary" (s. 77), a zadanie to osiągnął w swej pracy duszpasterskiej ks. H. Nouwen.

Natomiast Marta Bolińska zauważa obecność problematyki autyzmu, a także osób z zaburzeniami w powieści Doroty Terakowskiej $W$ krainie kota. Badaczka literatury zwraca uwagę na biblioterapeutyczny potencjał tkwiący w tej powieści, a także szerzej - w twórczości literackiej. Ponadto za pomocą postaci takich jak bohaterowie powieści Terakowskiej - Ewa czy Thet - czytelnicy mają możliwość zapoznać się z problemem funkcjonowania osób autystycznych, ich innością. Powieść Terakowskiej, stanowiąca w ocenie Bolińskiej „zaprzeczenie retoryki milczenia”, pozwala zwrócić uwage na konieczność budowania świadomości o osobach z autyzmem, podkreśla wagę ukazania inności jako niewykorzystanego potencjału, a tym samym pozytywnego wartościowania neuroróżnorodności, pełniąc zatem funkcję edukacyjną.

Przedostatni w tej części artykuł autorstwa Bożeny Chrostowskiej podejmuje ważki problem samorzecznictwa osób ze spektrum autyzmu. W aspekcie problemu kluczowego dla recenzowanego zbioru artykułów - komunikacji tekst Chrostowskiej zwraca uwagę na konieczność umożliwienia osobom ze spektrum mówienia we własnym imieniu, a tym samym konieczność uczenia (się) tej umiejętności, której - jak przekonuje badaczka - osoby autystyczne nie są w stanie nabyć samodzielnie. Dlatego też badaczka ukazuje za K. Sibley etapy nauczania i uczenia się umiejętności rzecznictwa własnych potrzeb (zob. tabela s. 103-104), a także podkreśla konieczność dostosowania procesu uczenia do możliwości danej osoby z uwzględnieniem adekwatnych metod komunikacji. B. Chrostowska przekonuje czytelnika do tego, że umiejętność rzecznictwa jest jedną z najważniejszych sprawności, których osiągniecie staje się gwarancją niezależności osób autystycznych. Co jednak ważne, niezależność tę należy zdaniem autorki rozumieć inaczej niż jest to przyjęte w społecznym uzusie. Chrostowska pisze bowiem: „To przesunięcie akcentów w definiowaniu niezależności, do której ma prowadzić nauka samorzecznictwa, wskazuje, moim zdaniem, że realizacja praw i potrzeb nie zależy tylko i wyłącznie od umiejętności/ nieumiejętności rzecznictwa własnych spraw osób ze spektrum (bo nie wszyscy są w stanie w efektywny 
sposób opanować składające się na tę dyspozycję kwalifikacje) ale, a może wręcz w głównej mierze, od jakości systemu społecznego, w którym przyszło im żyć. To od jego funkcjonowania (tworzących go rozwiązań prawnych, funkcjonalności rzeczywistego systemu wsparcia, opieki, edukacji, rehabilitacji, związanego z zatrudnieniem etc.) zależy w dużym stopniu ilość i jakość tworzonych opcji minimalizujących zależność od innych w realizacji swych potrzeb czy kreowanie jakości życia z pomocą" (s. 107). Autorka zwraca uwagę, że w Polsce ruch samorzeczników autystycznych dopiero zaczyna się rozwijać, a system wsparcia dla dorosłych osób ze spektrum w zasadzie nie istnieje. Podkreśla ona jednak, że w podnoszeniu kompetencji samorzecznictwa trzeba brać pod uwagę nie tylko umiejętności społeczne, lecz również kompetencje obywatelskie (wśród których wymienia m.in. wiedzę o swoich prawach) oraz efektywne przywództwo. W kontekście tym badaczka zwraca też uwagę na konieczność zwiększania świadomości społecznej na temat autyzmu.

Część drugą zamyka artykuł Elżbiety Fert, która w swym tekście przedstawia behawioralną propozycję badania umiejętności komunikacyjnych na podstawie VB-Mapp - programu do oceny tych umiejętności u osób ze spektrum autyzmu i innymi zaburzeniami. Autorka, językoznawczyni i logopeda, przedstawia zastosowanie programu w diagnozowaniu konkretnego przypadku - dziecka z zespołem Aspergera. Zauważa ona walory opisywanego instrumentarium diagnostycznego, wśród których wymienia: możliwość szczegółowego zbadania funkcji języka, określenia, czy zachowania werbalne danego dziecka są adekwatne do jego wieku i potrzeb, wskazania celów terapeutycznych służących usprawnieniu komunikacji, a także - co może się okazać istotne z perspektywy funkcjonowania dziecka w szkole - umożliwia stworzenie indywidualnego programu edukacyjno-terapeutycznego, który bazuje na propozycjach behawioralnych B. Skinnera.

Trzecią częścią publikacji jest zbiór tekstów specjalistów pracujących z osobami ze spektrum, w których omawiają oni różne aspekty terapeutyczne komunikacji osób z ASD. Ewa Boksa, odwołując się do badań Tomasella, Levinsona i Hollera, przedstawia zaburzenia komunikacji u osób ze spektrum autyzmu z uwzględnieniem filogenezy języka. Zwraca uwagę na konieczność nabywania umiejętności dzielenia uwagi, naśladownictwa, wskazywania palcem i współpracy stanowią podstawę przy osiąganiu dalszych postępów językowych. Z kolei Magdalena Nosko-Goszczyńska, neurologopeda kliniczny, przybliża czytelnikom, jakie możliwości terapeutyczne można osiągnąć za pomocą wczesnej interwencji AAC (wspomagające i alternatywne metody komunikacji). Autorka w swym tekście zmierzyła się z mitami na temat komunikacji AAC, a także przedstawiła na podstawie studium przypadku możliwości i sposoby korzystania z AAC w pracy z dzieckiem autystycznym.

Natomiast Anna Zając w swoich badaniach pokazuje różnice między rozumieniem ukrytych intencji przez dzieci z autyzmem i dzieci neurotypowe. Do przeprowadzenia tego badania autorka wykorzystała test fałszywych przekonań, a także test wykorzystujący maksymy konwersacyjne. Wyniki potwierdziły 
problem z mentalizowaniem i empatyzowaniem, a także umiejętnością wnioskowania na podstawie interpretacji mimiki czy tonu głosu, które występują u dzieci z ASD.

Ewa Bielecka-Nowakowka zwróciła uwagę na możliwości budowania relacji dziecko z autyzmem - terapeuta w oparciu o myślenie skojarzeniowe i teorię skryptów stanowiących schematy umysłowe, swego rodzaju scenariusze zachowań. Badaczka podkreśliła wagę myślenia wzorami charakteryzującą funkcjonowanie dzieci autystycznych, zwróciła jednak uwagę na konieczność treningu umiejętności społecznych w terenie, dzięki czemu „terapeutyzowanie” wyjdzie poza gabinet terapeutycznych i pozwoli budować doświadczenia w konkretnych sytuacjach społecznych. By dziecko mogło sprawniej funkcjonować w przestrzeni społecznej, badaczka postuluje rozwijanie różnych wzorów zachowań, a także ich modyfikowanie.

Tom kończy artykuł Kamila Lodzińskiego zatytułowany Wewnętrzne warstwy funkcjonalne. Responsywność wobec osób z autyzmem, w którym autor zwraca uwagę na rolę postawy responsywnej charakteryzującej działania terapeuty lub rodzica, opiekuna pracującego z dzieckiem z autyzmem. Podkreśla też wartość wspólnej uwagi w budowaniu relacji między partnerem responsywnym a dzieckiem z ASD. Autor zwraca uwagę na konieczność dostrajania się układów nerwowych partnera responsywnego i dziecka, które pomagają w tworzeniu wzajemnych relacji.

Opisywana tu publikacja wieloautorska Otwórzmy świat... stanowi lekturę wieloaspektową, podzieloną w zamyśle redaktorów na trzy segmenty, adresowane do różnych odbiorców. Pierwsza stanowi swego rodzaju zaproszenie dla każdego czytelnika do poznawania świata bez metafory, świata osób z autyzmem. Kolejna część to lektura adresowana głównie do naukowców, choć z uwagi na przystępny język poszczególnych tekstów, może też stać się lekturą dla tych, którzy po przeczytaniu pierwszego artykułu chcieliby dowiedzieć się więcej na temat różnych aspektów komunikacji osób z ASD. Ostatnia natomiast część, w moim odczuciu najbardziej specjalistyczna, stanowi swoiste forum doświadczeń specjalistów pracujących z dziećmi ze spektrum, forum mające charakter naukowy, z którego nawet rodzic może dowiedzieć się, jak ważna, choć trudna, jest komunikacja z dzieckiem ze spektrum i jak szukać możliwości skomunikowania się z własnym dzieckiem. Trzecia publikacja wydana w ramach działania Stowarzyszenia „Otwórzmy świat” nie tylko uświadamia czytelnikom, czym jest autyzm, lecz stawia kolejne kroki na drodze naukowego poznania komunikacyjnych barier związanych z autyzmem, a także stworzenia swoistego dialogu między specjalistami pracującymi z osobami autystycznymi nad dążeniem do „otwarcia świata” na potrzeby komunikacyjne osób ze spektrum. 